\title{
Pharmacokinetic Concentration End Date Time
}

National Cancer Institute

\section{Source}

National Cancer Institute. Pharmacokinetic Concentration End Date Time. NCI

Thesaurus. Code C87955.

The date and time a pharmacokinetic concentration assessment has concluded. 